\title{
Technology of Uninterruptable Shore-side Power Supply for Berthing Vessels and Its Application
}

\author{
Song Yan Qiong ${ }^{1,2, a}{ }^{*}$, Xiao, Le Ming ${ }^{1, b}$ \\ ${ }^{1}$ Guangzhou Maritime Institute, \#101 Hongshan 3 Rd,Guangpu District,Guangzhou,China,510725 \\ ${ }^{2}$ Wuhan University of Technology, \#1004 Path of Peace,Wuchang District,Wuhan,China,430063 \\ asongyqh@126.com, bx ${ }^{\mathrm{a}} \mathrm{m} 201 @ \operatorname{sina.com}$
}

\begin{abstract}
Keywords: intelligent control; shore-side control ring current; uninterruptable power; shore-side power connection.

Abstract. As the international maritime organization made mandatory for ship's atmospheric emission pollution control requirements in MARPOL6 convention in 2013, shore-side power technology applications in the domestic and foreign port can realize the effective control of atmospheric pollution to ships berthing in Emission Control Areas (ECAs) of ports. Upon the technology of seamless shore-side power supply for berthing vessels, shipboard electric power grid and shore-side power system can be connected using the cable connection and switch at first, utilizing shore control intelligent synchronous system as the core, on the one hand, when the berthing ships need to connect shore-side power intelligent shore control ring current methods can be taken to accomplish the effect of average voltage control and automatic synchronization for marine generators, and then shore-side power electricity can be merged into the shipboard electric power without changing the ship power station basically, and consequently marine electricity generators can be switched off ; On the other hand when shore-side power need to disconnect breaker, tripping shall be controlled using inrush ring current control circuit, as well as connecting the reactor, if limiting current and average voltage control and automatic synchronization are completed marine electricity generators ship can be paralleled into shore-side power system and then shore-side power can be disconnected.
\end{abstract}

\section{Introduction}

According to the latest international and national laws and port regulations for shipboard discharge atmospheric pollution control e.g. MARPOL6 of the mandatory requirements, the shore-side power box for berthing ship have be equipped to connect shore-side power in most ports at domestic and abroad, which can make realize berthing vessels energy and cost savings and emission reduction for environmental protection in Emission Control Areas (ECAs) of ports. A ferry sailing between Poland and Sweden, for example, in year 2012, 3 hours every day berthing in Poland port, 7 hours berthing in Sweden port, the costs on fuel oils consumption for marine electricity generators of prime mover and shore-side power generation, were \$724 and \$356 respectively in Swedish port, as well as \$1759 and $\$ 678$ respectively in Poland port, the cost can be saved for $\$ 1449$ every day if the ferry berthing in the ports directly connect shore-side power. Furthermore, MariTerm AB consulting report points out that in EU countries emissions and noise of the direct costs are about 10 times above as more as the indirect costs on heavy diesel oil burning consumption for shipboard electricity generation.

In China, Tianjin port, which attempts to build the international cruise yard, plans to have 6 berths, the coastal line of $2000 \mathrm{~m}$ and can make the world's largest cruise docked at the wharf, with passengers volume of 500,000 every year, meanwhile, in the port area can increase the port services, restaurants, business centers, office buildings and other supporting facilities in the future, in order to meet the future development of the port. For such large ports it should be considered that mandatory application of cable laying and shore power. If the mandatory application in the area for shore power, not only atmospheric pollutions can be effectively reduced, but also the berthing ships hotel operation can be realized so as to prompt the regional economic development. Therefore, the measure of specifying the shore power mandatory application area is effective. 
In order to reduce atmospheric emission pollution in ECAs of ports for berthing ship burning inferior heavy fuel oil when starting marine diesel engine donkey machines, the United States and other foreign countries increase investment in the project on shore-side power technology, the ministry of transport in China shore-side power technology also was included in the 12th five-year plan, China's coastal ports (Dalian, Tianjin, Qingdao ports in the north of China and economic delta zone ports in the south) need to be forced to connect shore-side power in the future. So in following parts the technology of seamless shore-side power supply for berthing vessels will be discussed.

\section{The shore power technology in China and abroad}

The ferry between Poland and Sweden earlier adopts the high voltage frequency conversion ship-side power supply system (see Figure 1), which can converse the frequency of high voltage, and then regulate the voltage on the ship [1], via installing special synchronous device beside the ship power distribution cabinet, realizes the seamless connection of shore power, ships in the United States replace with amp (alternative maritime power system). In the ship for higher intelligence of seamless connection on-shore power synchronous control, they only adapt to the professional ships and quays.

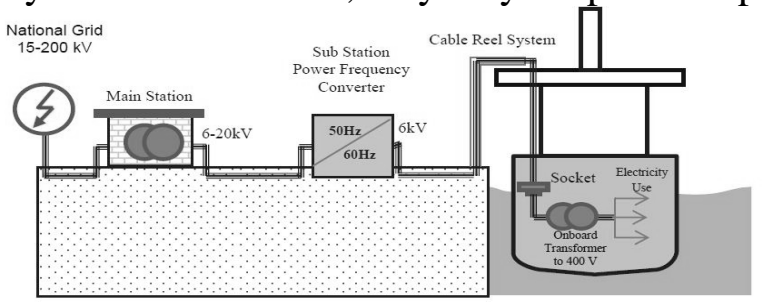

Fig.1: The high voltage frequency conversion ship-side power supply system diagram for berthing ferry

For Lianyungang port in China, on-shore power technology also belongs to the same principle, which belongs to the high voltage variable frequency control on board seamless connection [2].

Marine on-shore power supply system widely used in China and abroad is divided into three parts: the on-shore power supply system, the cable connection device, and ship electrical system [3].

Alternative maritime power system in the United States belongs to the type of seamless on-shore power connected to the ship without frequent converting[4], when the ship has connected shore power supply system during the period of berthing, the management system dominates marine electric power management system, and controls marine electrical voltage, phase and frequency, etc., as well as, adjusts to matching the characteristics of the shore power when it can achieve instantaneous paralleling operation between two power systems, then performs the operation of the load transfer, so as to complete the alternating of power supply.

In reference [5] the characteristics and development of ship-side power system were introduced, and the problems about that shore-side power supply is not matching and power supply system is not unified were analyzed, meanwhile, the problems of existing vessels` shore power reconstruction scheme were put forward, and comparison of various shore power technology was also given. And the authors suggests using a new type of shore power technology i.e., compatible TN and IT system.

The importance of berthing vessels connect shore-side power in order to realize green environmental protection, energy saving and emission reduction is discussed in reference [1] - [6].

\section{A low-voltage intelligent shore-side controlling uninterruptable shore power system}

Shore controlling ring current low voltage uninterruptable shore power connection structure is as shown in Figure 2. As the intelligence platform with industrial control computers, at first acquire electrical parameter signals i.e., shore power current, shore power voltage and power factor, and acquire ring current signal when shipboard power grid have connected to shore power, and then control the reactor switch on or off and automatic synchronization in order to uninterruptedly connect shore power. Meanwhile, the intelligence platform according to $400 \mathrm{~V} / 50 \mathrm{~Hz}$ or $450 \mathrm{~V} / 60 \mathrm{~Hz}$ shipboard rating, can control directly connect or through frequency conversion to shore power, through wireless information between the ship and the intelligence platform finish sending the 
electricity type and power signal, intelligent platform can accept them; at the same time when the intelligence platform send electricity consumption and electricity fee, ships can also accept them. Intelligence platform control transformer voltage with marine generators control panel, load transfer can be realized, as well as intelligence platform can use for data display and all kinds of fault alarm. The intelligent platform and intelligent power supply system in the wharves can form intelligent ports.

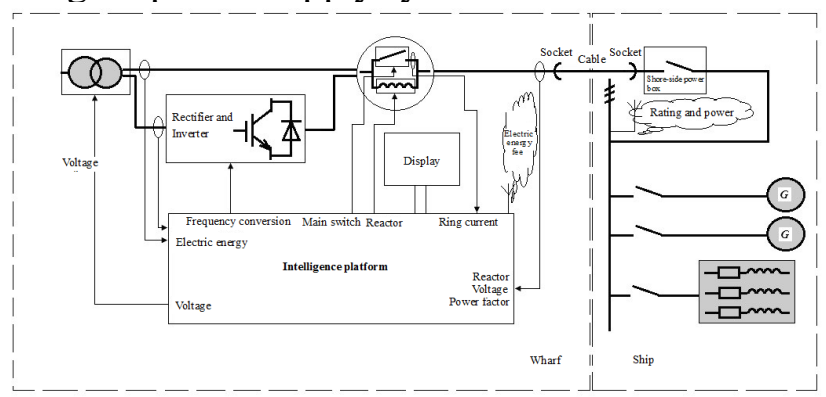

Fig.2 The shore-side controlling ring current uninterruptable shore power connection structure

\section{Cable connection and switch Settings}

By setting up multiple cables in parallel, to set a large cable parallel connection in shipboard shore power box, according to the load and the pressure drop of the cable with 1 to $\mathrm{n}$ cables in parallel, the weight of which is convenient for a person finishing connection from the shore, and cable winch still can be added.

If cable capacity is set as $I_{1}$, length is $L$, resistivity is $\rho$, the cross-sectional area is $S$, the cable number is $n$, the pressure drop is $5 \mathrm{~V}$, and ship load is $I_{\mathrm{N}}$, then $n \geq I_{N} / I_{1}$, and $n \geq I_{1} \rho L / S / 5$.

When the interlock control is set between the ship shore power box and marine generator, special clamps insulation type wires for temporary uninterruptable shore power connection can be used, and in shore-side power box the location of normally closed interlock contact shall be determined according to electricity generators main switch's relative to shore power system main switch, and then the operators attempt to short the normally closed contact, who should pay attention for the live working. Meanwhile in shore-side power box the location of interlock contact shall be determined according to shore power system main switch's relative to electricity generators main switch, and then the operators attempt to loosen the contact and also Wrapped by insulation sleeve.

When the berthing vessels determine to connect shore-side power, there is a change-over switch in the shore power box, which has two switching positions, one is uninterruptable shore power connection, and the other is off-position shore power connection on the original state.

\section{The intelligent shore-side controlling ring current methods}

About intelligent shore-side controlling circulation current, Ericsson $\mathrm{P}$ the berthing ships multi-connected shore power system at the same time modeling and analysis may provide the reference for building wisdom port [7], learning from that modeling and simulation analysis for the constant frequency of shaft generator and variable frequency diesel generator in the mode of paralleling operation by scholars in China and abroad [8], with the aid of engineering calculation software MATLAB powerful mapping function by simulating the process of generators paralleling [9]. Research on hybrid current limiting circuit breaker of current rising rate, current limit and breaking action time[10], will contribute to improving the reactor selection and circuit breaker current setting when using intelligent shore-side controlling circulation current methods.

To realize ring current control digitization, computer control loops should be reasonable, and output drive control should be reliable, and control object will comprehensively. In terms of scientifically controlling ring current, after connecting cables automatic paralleling will be finished in 15 seconds, and when receiving electrical signals the marine diesel generators will be stopped within 1 minute. With reactor connected breaker of action current and circulation current $(\mathrm{QFb})$ tripping the reactor will be connected, at the same time successful paralleling connect can indicate within 15 seconds; the 
cooperation between $\mathrm{QFb}$ action current, shore power box and generators circuit breaker short-circuit protection should be reliable, without wrong action.

About shore-side control ring current, the tripping current and time is to be determined when reactor is connected to the circuit breaker in accordance with rush current changing rule, and the mathematics modeling of the system can be constructed through adopting the parameters of transformer in actual port and the berthing ships ' marine electricity generators in the various ultimate state of load mutation, at the same time, the strict tests should be carried according to QFb tripping reliability in view of the limit state, and as well as short circuit protection reliability among QFb, shore power box and generator circuit breaker, meanwhile, parameters can be adjusted and rectified, finally to determine the tripping current levels and ranges for QFb setting tripping.

In view of restricting ring current reactor is certain, the too large valve of $X$ is to determine that effect of average voltage control and automatic synchronization become weaken, easily lead to generator long-time reverse power to trip and failure paralleling. The resolving methods is to consider the reactors valve of actual marine electricity generators and cable impedance for connected between ship and shore, and to pay attention for the possible impact of inrush load, and to establish accurate mathematical model , and to determine the levels and the ranges of reactor, then rectifying by tests.

\section{Conclusions}

The technology of uninterruptable shore-side power supply for berthing vessels and its application, without changing the ship power station basically in the basic no change of ship power station, can prompt Chinese ports to generally realize uninterruptable shore-side power supply quickly and easily for the berthing ships. Although the cost on inferior heavy fuel oils consumption for marine electricity generators of prime mover for the berthing ships in the ports is low, the extra cost of atmospheric emission pollution processing in ECAs of ports greatly increases, and even irreversible harm to environment and nearby residents may not be able to reverse. Therefore the technology of uninterruptable shore-side power supply for berthing vessels and its application can ensure that economic benefits and social benefits of total energy conservation and environmental protection will be more and more significant.

\section{References}

[1] Borkowski T, and Tarnapowicz D. "SHORE TO SHIP" SYSTEM-AN ALTERNATIVE ELECTRIC POWER SUPPLY IN PORT. Journal of KONES Powertrain and Transport, Vol.19,No.3(2012).

[2] ZHANG Guoqiao, and MU Xin. Study on the shore power technology for green port construction, through investigating shore-side power for vessels in Lianyungang port (in Chiese). Port Economy, No.1,36-38(2011).

[3] LIU Hong-bo, and DONG Zhi-qiang, LIN Jie-qing.On the technology of on-shore power supply for vessels(in Chiese). Port \& Waterway Engineering, No.9,181-184(2011).

[4] LI Xuewen, and SUN Keping. On shore-side power for vessels in ports.Journal of Shanghai Maritime University, No.3,10-14(2006).

[5] WU Zhengfei, and YE Xiaosong, and XING Ming. Talk about the key shore power technology for berthing ships(in Chiese). Electrotechnical Application,No.6,22-26(2013).

[6] MariTerm AB. Shore-side electricity for ships in ports[R]. (2004-07-06)[2010-05-15]. http://www.ops.wpci.nl/_images/downloads/_original/1264090795_2004maritermshore-sideelect ricityforshipsinports. pdf, 2004.

[7] Ericsson P, and Fazlagic I. Shore-side power supply. Master of Science Thesis-Chalmers University of technology, Goteborg Sweden(2008).

[8] GAO Haibo, and CHEN Mingzhao, and CHEN Hui. Design and Modeling of the Ship Shaft Generator Simulator(in Chiese). JOURNAL OF SYSTEM SIMULATION,No.6, 806-808(2002). 
[9] WANG Chen, and ZHUANG Jinwu, and JIANG Zhuangsian, et al.Analysis of current limiting characteristics and commutation arc energy of improved hybrid current limiting circuit breaker(in Chiese). High Voltage Engineering, No.6, 1365-1371(2012).

[10]Eman,O.E. Interactivebi-level multi-objective integer non-linear programming problem.Applied Mathematical Sciences, Vol.5,No.65, 3221-3232(2011). 